\title{
Global \& Community Health: Neurologic care for Latinos in South Philadelphia
}

\section{Global health at home}

Susanna S. O'Kula, MD, Whitley W. Aamodt, MD, and Michael N. Rubenstein, MD

Neurology ${ }^{\circledR}$ 2019;93:461-462. doi:10.1212/WNL.0000000000008073
Correspondence

Dr. O'Kula

susanna.o'kula@

nyulangone.org

On the first Wednesday of each month, 2 neurology residents and an attending from the University of Pennsylvania see patients who lack insurance at Puentes de Salud (Bridges of Health), a nonprofit organization that offers education, health care, and social services to South Philadelphia's Latino immigrant community. On one such evening, I met Carla (name changed to protect patient privacy), who presented for evaluation of a possible seizure disorder. Carla was initially seen by a local doctor in Guatemala and prescribed carbamazepine for events in which she would lose consciousness and bite her tongue. If she felt afraid or anxious, she would take an additional tablet as needed. These episodes coincided with physical and emotional abuse she experienced at the hands of her children's father, and they resolved after she left her abuser. She had no epilepsy risk factors and had not experienced an event in over 8 years.

After performing a thorough, unremarkable neurologic examination, I stepped out of the room. Although we commonly encounter patients who take antiepileptic medications for suspected nonepileptic events, Puentes de Salud is no ordinary clinic. Since 2006, Puentes de Salud, known locally as "Puentes," has offered low-cost, high-quality medical care to Philadelphia's Latino community. ${ }^{1}$ This oasis is welcome in a city where $25.3 \%$ of the population lives in poverty. According to 2016 census data, $14.8 \%$ of the Philadelphia population identified as Hispanic or Latino. ${ }^{2}$ Although Philadelphia's US-born population fell by 44,500 from 2000 to 2016 , the immigrant population grew by approximately 95,000 over the same period. In 2014, a quarter of Philadelphia's foreign-born population, roughly 50,000 residents, was undocumented. ${ }^{3}$ While Puentes has long provided primary medical care, the organization addressed the lack of access to specialty care in recent years by partnering with specialists from the University of Pennsylvania. Our neurology residency program developed a relationship with Puentes in 2016. Today, this monthly rotation is part of our program's Global Health and Health Equities Firm, an optional track within our residency that is designed to educate residents through monthly conferences and outreach opportunities at local clinics and our global site in Karatu, Tanzania.

The structure of Puentes is similar to that of our resident clinic, but it is held in the evenings, when more patients are available after work. Medical interpreters are provided for residents and attendings who do not speak Spanish. Certain studies, such as EEG, CT, and MRI, are not easily afforded or obtained, so our neurologic care must be thoughtfully delivered. Laboratory tests are available and cost between $\$ 5$ and $\$ 15$ per test. We prescribe the same medications as in our clinic but take extra care in searching for coupons and pharmacies that offer these medications at a lower price. Puentes also has a Health Insurance Portability and Accountability Actcompliant electronic medical record that promotes continuity of care as neurology residents rotate from month to month. Clinic volume ranges from 6 to 10 patients per evening and is incredibly varied. I frequently ask patients where they are from in an effort to distract while I check their reflexes, but more often than not, I am the one distracted by their stories. Patients are commonly from Guatemala, Mexico, Ecuador, and the Dominican Republic, and many have left children and parents back home. While some work multiple jobs, others are unemployed 
and living with supportive family members. Though most chief complaints encompass migraine, epilepsy, and carpal tunnel syndrome, some cases involve considerable psychosocial and neurologic complexity.

After discussing Carla's case with my attending, I returned to her room. We discussed the difference between epileptic and nonepileptic events in addition to the long-term side effects of carbamazepine. She had no discernible side effects, and we developed a taper plan to avoid withdrawal symptoms. Although she ultimately agreed to this plan, suspicion shone in her eyes as we challenged the diagnosis she had carried for a decade. I knew it would require multiple conversations to build rapport with a woman who had arrived in this country only 3 months prior. Given the sensitive nature of nonepileptic events, she was also provided with a referral to see behavioral health, a relatively new service offered at Puentes.

As I waved goodbye to Carla, one of our patients with a more complicated case arrived for a follow-up visit. Mariluz (name changed to protect patient privacy) was diagnosed with neurosarcoidosis after an inpatient stay at the Hospital of the University of Pennsylvania where she underwent an MRI of her brain and spine, a lumbar puncture, and numerous serologies. She was discharged on a high dose of prednisone, and that evening she complained of arthralgias, acne, weight gain, and mood fluctuations. She had lost insurance since her initial hospitalization, so we were unable to repeat an MRI or other diagnostics. Her examination was reassuring and notable only for increased tone in her lower extremities. After conferring with my attending, we discussed initiating a steroid taper and an immunosuppressive agent. As the visit was ending, she asked in Spanish about neurosarcoidosis. While I was certain multiple providers had explained this diagnosis to her, I comprehended that the gulf in understanding often requires multiple attempts to traverse. Even as I began a cursory explanation of neuroimmunology, I worried that these details were too complex. Armed with an UptoDate page translated into Spanish and multiple paper prescriptions, she disappeared into the night. After a busy evening in clinic, the last patient left at close to 9 o'clock.

During each visit, there are often unspoken chief complaints, and some nights we are exhausted by our patients' needs. Many residents, however, cite this clinical experience as one of the highlights of their residency. Both Carla's and Mariluz's visits illustrate the similar yet distinct challenges of providing care at Puentes. Carla returned the next month just before her carbamazepine ran out. She was seizure-free but still prone to panic attacks. Although she had not yet seen behavioral health, she was started on fluoxetine. Mariluz also returned the following month on the same steroid dose as before, having misunderstood the taper instructions. She was transitioned to azathioprine. For Carla, it took a second appointment to build trust in a foreign culture and country; for Mariluz, the language barrier required another follow-up visit to prompt a change in management. Our monthly presence at Puentes provides us with regular opportunities to address and overcome these perceived barriers.

As more residency programs offer educational electives abroad, ethical issues often arise surrounding cultural differences and the allocation of scarce resources in medically underserved communities. Many of these dilemmas have been described in the medical literature on global health outreach work. ${ }^{4}$ However, the opportunity to practice neurology at Puentes de Salud confronts similar issues despite remaining closer to home. Our neurology residents gain exposure to a clinical environment in which tools and tests are limited or unavailable, and we hope that this partnership model between an academic residency program and local clinic is applicable to other residency programs nationwide. In a country in which much, including the predominant language, remains foreign to immigrants, our mission is to make their physician-patient relationship more familiar and compassionate.

\section{Author contributions}

S.S. O'Kula contributed to concept and design and drafting and revising the manuscript. W.W. Aamodt contributed to drafting and revising the manuscript. M.N. Rubenstein contributed to study supervision or coordination.

\section{Study funding}

No targeted funding reported.

\section{Disclosure}

S.S. O'Kula reports no disclosures relevant to the manuscript. W.W. Aamodt is a member of the Neurology ${ }^{\circledR}$ Resident \& Fellow Section team. M.N. Rubenstein reports no disclosures relevant to the manuscript. Go to Neurology.org/N for full disclosures.

\section{References}

1. Puentes de Salud. Our services. Available at: puentesdesalud.org/services/. Accessed January 5, 2019

2. US Census Bureau, US Department of Commerce. Philadelphia County, PA. Available at: census.gov/quickfacts/philadelphiacountypennsylvania. Accessed January 5, 2019.

3. Eichel L, Ginsberg T. How Philadelphia's immigrant population compares with other major US cities. The Pew Charitable Trust. 2018. Available at: pewtrusts.org/en/ research-and-analysis/articles/2018/07/06/how-philadelphias-immigrant-population-compares-with-other-major-us-cities. Accessed January 5, 2019.

4. Harrison JD, Logar T, Le P, Glass M. What are the ethical issues facing global-health trainees working overseas? A multi-professional qualitative study. Healthcare 2016;4: E43. 


\section{Neurology}

\section{Global \& Community Health: Neurologic care for Latinos in South Philadelphia: Global health at home}

Susanna S. O'Kula, Whitley W. Aamodt and Michael N. Rubenstein

Neurology 2019;93;461-462

DOI 10.1212/WNL.0000000000008073

This information is current as of September 2, 2019

Updated Information \& Services

References

Subspecialty Collections

Permissions \& Licensing

Reprints including high resolution figures, can be found at: http://n.neurology.org/content/93/10/461.full

This article cites 1 articles, 0 of which you can access for free at: http://n.neurology.org/content/93/10/461.full\#ref-list-1

This article, along with others on similar topics, appears in the following collection(s):

Access to care

http://n.neurology.org/cgi/collection/access_to_care

All Education

http://n.neurology.org/cgi/collection/all_education

All global neurology

http://n.neurology.org/cgi/collection/all_global_neurology

Inclusion, Diversity, Equity, Anti-racism, and Social Justice (IDEAS)

http://n.neurology.org/cgi/collection/all_equity_diversity_and_inclusio $\mathrm{n}$

Underserved populations

http://n.neurology.org/cgi/collection/underserved_populations

Information about reproducing this article in parts (figures,tables) or in its entirety can be found online at:

http://www.neurology.org/about/about_the_journal\#permissions

Information about ordering reprints can be found online:

http://n.neurology.org/subscribers/advertise

Neurology ${ }^{\circledR}$ is the official journal of the American Academy of Neurology. Published continuously since 1951 , it is now a weekly with 48 issues per year. Copyright @ 2019 American Academy of Neurology. All rights reserved. Print ISSN: 0028-3878. Online ISSN: 1526-632X.

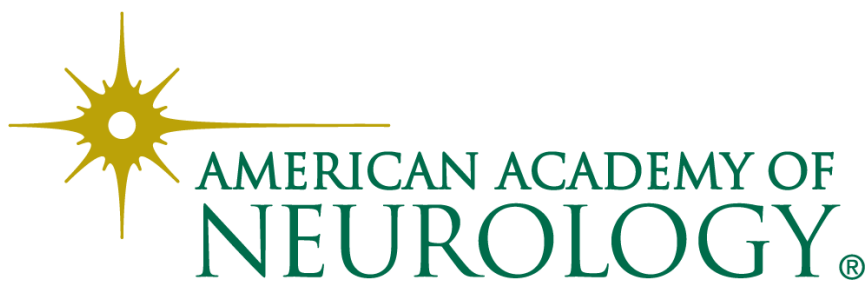

